\title{
PENGARUH PEMBELAJARAN KOOPERATIF TIPE TEAMS GAME TOURNAMENT BERBANTUAN MEDIA TEKA-TEKI SILANG TERHADAP MOTIVASI SISWA PADA MATERI KOLOID
}

\author{
Selviana Safitri' ${ }^{1}$, Rizmahardian A Kurniawan², Raudhatul Fadhilah ${ }^{3}$ \\ 1,2,3 Program Studi Pendidikan Kimia Fakultas Keguruan dan Ilmu Pendidikan \\ Universitas Muhammadiyah Pontianak, Jalan Jendral Ahmad Yani \\ 1e-mail: selvianasafitri27@gmail.com
}

\begin{abstract}
Abstrak
Penelitian bertujuan untuk mengetahui pengaruh pembelajaran kooperatif tipe teams game tournament berbantuan media teka-teki silang terhadap motivasi belajar siswa pada materi Koloid. Penelitian menggunakan metode eksperimen dengan rancangan penelitian nonequivalent control group design. Populasi penelitian adalah siswa kelas XI IPA yang berjumlah 120 siswa. Sampel penelitian yaitu siswa kelas XI IPA 1 dan XI IPA 3 yang berjumlah 80 siswa menggunakan teknik purposive sampling. Teknik pengumpulan data menggunakan komunikasi langsung dan observasi langsung. Alat pengumpul data menggunakan panduan wawancara dan pedoman observasi. Hasil penelitian menunjukkan bahwa: (1) Model pembelajaran kooperatif tipe teams game tournament berpengaruh terhadap motivasi siswa sebesar 96,64\%; (2) Terdapat perbedaan motivasi belajar siswa yang diajarkan dengan teams game tournament berbantuan media teka-teki silang dan metode ceramah pada materi Koloid; dan (3) Nilai effect size motivasi siswa sebesar 1,83.
\end{abstract}

Kata Kunci: teams game tournament, motivasi siswa, teka-teki silang.

\begin{abstract}
This study aims to determine the influence of cooperative learning type teams game tournament based crossword puzzle-assisted towards students' motivation on colloidal material. This research used the experimental method with nonequivalent control group design. Population were students of class XI IPA with 120 students. Samples were students of class XI IPA 1 and XI IPA 3 with 80 students selected by purposive sampling technique. The techniques to collect data were direct communication and direct observation methods. The tools to collect data were interview guidlines and observation guidlines. The results showed that: (1) Cooperative learning type teams game tournament based crossword puzzle-assisted influenced by students' motivation with 96,64\%; (2) There are differences in students' learning motivation on the colloidal material of students taught by cooperative learning type teams game tournament based crossword puzzle-assisted and conventional learning; and (3) The value of effect size of students' motivation is 1,83.
\end{abstract}

Keywords: teams game tournament, students' motivation, crossword puzzle.

\section{PENDAHULUAN}

Kata motivasi berasal dari kata "motif" yang diartikan sebagai daya upaya yang mendorong seseorang untuk melakukan sesuatu. Motivasi adalah perubahan energi dalam diri seseorang yang ditandai dengan munculnya feeling dan didahului dengan tanggapan terhadap adanya tujuan. Untuk mencapai tujuan- 
tujuan tersebut motivasi memiliki beberapa komponen yang berpengaruh. Motivasi memiliki dua komponen, yaitu komponen dalam (inner component) dan komponen luar (outer component). Komponen dalam merupakan kebutuhan yang ingin dipuaskan dan komponen luar merupakan tujuan yang hendak dicapai (Hamalik, 2011). Motivasi merupakan salah satu faktor yang mempengaruhi hasil belajar siswa. Dengan adanya motivasi, siswa akan belajar lebih keras, ulet, tekun, dan memiliki konsentrasi penuh dalam proses pembelajaran (Hamdu dan Agustina, 2011).

Motivasi siswa dalam kegiatan pembelajaran Kimia di SMA Negeri 9 Pontianak masih sangat rendah dikarenakan siswa menganggap bahwa mata pelajaran Kimia merupakan mata pelajaran yang sulit. Rendahnya motivasi siswa juga terlihat pada saat observasi proses pembelajaran dikelas XI IPA 3. Hasil observasi menunjukkan bahwa selama proses pembelajaran siswa jarang mengambil peran aktif pada saat proses pembelajaran berlangsung seperti mengacungkan tangan pada saat guru bertanya tentang materi yang disampaikan. Siswa cenderung hanya berdiam diri pada saat guru menjelaskan dan terkadang terlihat siswa yang berbicara dengan temannya. Pada saat guru memberikan tugas untuk dikerjakan secara berkelompok, siswa terkadang hanya mengharapkan jawaban dari satu teman yang dianggap paling bisa dalam pelajaran Kimia, sedangkan siswa lainnya hanya bersantai dan berbicara dengan teman lainnya.

Salah satu materi Kimia yang diajarkan di kelas XI adalah materi Koloid. Materi Koloid memiliki karakteristik yang bersifat hafalan. Hasil wawancara kepada siswa yang telah dilakukan, mengungkapkan siswa akan cepat merasa bosan jika materi yang bersifat hafalan disajikan hanya dalam metode ceramah saja. Siswa kurang termotivasi jika pembelajaran hanya menggunakan metode ceramah. Motivasi siswa dalam pelajaran Kimia dapat ditingkatkan dengan cara menerapkan model pembelajaran yang berpusat pada siswa (student centered learning). Salah satu model pembelajaran berpusat pada siswa yang tepat pada materi Koloid yang sifatnya hafalan yaitu model pembelajaran kooperatif tipe Teams Games Tournament (TGT). Model kooperatif tipe TGT merupakan pembelajaran yang kegiatannya lebih berpusat pada siswa, siswa dibagi dalam 
kelompok-kelompok kecil yang terdiri dari 4-6 orang yang dipilih secara heterogen. Soebagio (2000) menyatakan bahwa model pembelajaran kooperatif tipe TGT merupakan strategi bagi pembelajaran sains di sekolah menengah karena dapat dilakukan secara luwes dan memenuhi kebutuhan nyata pengajar dan pembelajar. Model pembelajaran kooperatif tipe TGT merupakan model pembelajaran yang mengandung unsur permainan sehingga akan membuat siswa belajar dengan suasana yang menyenangkan sehingga materi yang diberikan akan mudah diserap dan diingat siswa.

Model pembelajaran kooperatif tipe TGT dalam penerapannya dapat dikembangkan menggunakan pemanfaatan berbagai media, diantaranya dengan menggunakan Teka Teki Silang (TTS). TTS sangat mudah untuk dibuat oleh guru dan dapat digunakan untuk semua tingkatan, baik untuk pemula, menengah atau yang sudah lanjut dan materi dapat dipilih sesuai dengan tujuan pembelajarannya (Khalilullah, 2013). Berdasarkan permasalahan dan fakta yang telah disampaikan, perlu dilakukan suatu penelitian untuk mengkaji pengaruh penggunaan model pembelajaran kooperatif tipe TGT dengan berbantuan media TTS terhadap motivasi pada materi Koloid. Dilihat dari keunggulan dengan menerapkan model pembelajaran kooperatif tipe TGT dengan media TTS, penelitian dilakukan untuk meneliti pengaruh model pembelajaran kooperatif tipe TGT terhadap hasil motivasi siswa.

\section{METODE}

Metode penelitian menggunakan metode eksperimen. Jenis penelitian yang dilakukan adalah quasi experimental atau eksperimen semu. Rancangan penelitian yang digunakan yaitu rancangan One-Shot Case Study. Populasi penelitian adalah siswa kelas XI IPA SMA Negeri 9 Pontianak tahun ajaran 2016/2017 yang terdiri dari XI IPA 1, XI IPA 2, dan XI IPA 3. Jumlah keseluruhan siswa kelas XI IPA yaitu 120 siswa. Jumlah siswa tiap-tiap kelas dari kelas XI IPA 1, 2 dan 3 yaitu 40 siswa. Sampel penelitian yaitu kelas XI IPA 1 dijadikan sebagai kelas eksperimen yang akan diberikan perlakuan berupa penerapan model pembelajaran kooperatif 
tipe TGT dan kelas XI IPA 3 dijadikan kelas kontrol dengan menerapkan metode ceramah.

Teknik pengumpulan data menggunakan teknik komunikasi langsung dan observasi langsung dengan alat pengumpul data yaitu panduan wawancara dan pedoman observasi. Teknik analisis data menggunakan statistik deskriptif dan inferensial dengan melakukan uji Normalitas (Kolmogorov Smirnov), uji U-Mann Whitney, Uji F, Uji t, dan effect size.

\section{HASIL DAN PEMBAHASAN}

Proses pembelajaran yang dilakukan di kelas kontrol dengan menggunakan metode ceramah membuat siswa menjadi pasif dalam kegiatan pembelajaran. Siswa terlihat pasif pada saat guru memberikan pertanyaan, tidak ada siswa yang menjawab dan pada saat guru menunjuk siswa barulah siswa tersebut menjawab pertanyaan dari guru. Berbeda di kelas eksperimen, siswa di kelas kontrol diberikan tugas berupa menjawab soal-soal yang terdapat di dalam buku paket siswa. Di kelas kontrol siswa terlihat tidak percaya diri dan hanya ada beberapa siswa yang aktif mendengarkan guru pada saat penyampaian materi. Tahapan dalam pembelajaran dengan menggunakan metode ceramah terdiri dari tahap awal, inti, dan akhir.

Pembelajaran kooperatif tipe TGT berbantuan media TTS, dalam pelaksanaannya berlangsung selama 5 tahapan yaitu penyajian kelas, pembentukan kelompok, games, tournament, dan team recognize. Model pembelajaran TGT melibatkan peran seluruh siswa sebagai tutor sebaya dan mengandung unsur permainan. Model pembelajaran kooperatif memberikan peluang kepada siswa untuk belajar lebih rileks dan menumbuhkan tanggung jawab, kerja sama, persaingan sehat, dan keterlibatan dalam belajar (Mulyatiningsih, 2012). Tahap penyajian kelas berisi penyajian materi yang disampaikan oleh guru. Penyajian materi dilaksanakan secara singkat selama 15 menit dan diikuti dengan sesi tanya jawab selama 10 menit. Selama sesi tanya jawab berlangsung, siswa dengan semangat mengacungkan tangan ingin menjawab pertanyaan yang diberikan oleh guru. 
Tahapan selanjutnya adalah tahap pembentukan kelompok. Siswa dibagi menjadi 8 kelompok belajar yang dipilih berdasarkan urutan daftar hadir kelas masing-masing terdiri dari 5 siswa. Siswa diminta untuk duduk berkelompok sesuai dengan kelompok yang sudah ditentukan oleh guru. Penentuan kelompok didasarkan pada daftar hadir siswa. Kelompok yang terbentuk merupakan kelompok heterogen yaitu terdiri dari siswa dengan kemampuan yang berbeda. Siswa diberi tugas berupa mengisi teka-teki silang untuk belajar bersama dengan kelompoknya agar dapat memahami materi pelajaran. Siswa semakin semangat dalam mengikuti proses pembelajaran dengan model TGT.

Teka-teki silang yang digunakan sebagai media pembelajaran pada penerapan model pembelajaran kooperatif tipe TGT bertujuan untuk memudahkan siswa dalam memahami materi yang telah disampaikan oleh guru, sehingga siswa dapat dengan mudah memahami suatu materi dengan menggunakan suatu media permainan. Penggunaan media TTS hanya digunakan di kelas eksperimen saja. Di kelas kontrol guru hanya menjelaskan dan memberikan tugas yang ada di buku pegangan masing-masing siswa. Hal tersebut termasuk tahapan yang membedakan pembelajaran di kelas kontrol dan kelas eksperimen.

Pembelajaran kooperatif tipe TGT dilanjutkan pada tahap permainan (game). Guru menyiapkan pertanyaan yang terdiri dari 4 soal untuk menguji pengetahuan yang diperoleh siswa dari penyajian kelas dan belajar kelompok sebelumnya. Kelompok yang dapat menjawab pertanyaan dengan benar akan mendapat skor dan akan dikelompokkan berdasarkan kategori kelompok rendah (40-60), sedang (60-80) dan tinggi(80-100) untuk lanjut ke babak turnamen. Kelompok yang termasuk dalam kategori sedang pada pertemuan pertama adalah kelompok 2,4,7, dan 8 sedangkan kelompok yang termasuk kategori tinggi adalah kelompok 1,3,5, dan 6. Pada pertemuan kedua, kelompok yang termasuk kategori sedang adalah 1,2,4, dan 6 sedangkan kelompok yang termasuk kategori tinggi yaitu kelompok 3,5,7, dan 8. Siswa sangat aktif dalam proses pembelajaran berlangsung dan menunjukkan sikap yang kompetitif terhadap kelompok lainnya. 
Siswa akan melakukan permainan akademik di babak turnamen yaitu dengan cara berkompetisi dengan anggota tim yang memiliki kemampuan setara dari kelompok yang berbeda. Soal pada tahap turnamen terdiri dari 3 soal pada masing-masing kategori, yaitu kategori rendah, sedang, dan tinggi. Siswa pada setiap pertemuan diturnamenkan berdasarkan kategorinya. Siswa saling beradu kecepatan untuk mengumpulkan soal turnamen terlebih dahulu, karena jika pertanyaan dijawab benar dengan waktu yang paling cepat, maka kelompok tersebut akan mendapatkan penghargaan. Siswa sangat bersemangat dalam mengerjakan soal dan ingin secepat mungkin dalam mengumpulkan jawaban soal turnamen. Hal tersebut disebabkan karena siswa dalam tiap kelompok memiliki sikap kompetisi yang tinggi dan berkeinginan menjadi pemenang dalam turnamen. Kelompok yang memenangkan turnamen pada pertemuan pertama adalah kelompok 7 dan kelompok 3, sedangkan pada pertemuan kedua yang memenangkan turnamen adalah kelompok 2 dan kelompok 1.

Team recognize merupakan tahapan terakhir dalam model pembelajaran kooperatif tipe TGT, yaitu tim yang menunjukkan kinerja paling baik akan mendapatkan penghargaan. Penghargaan yang diberikan berupa bingkisan sederhana dari guru. Pemberian penghargaan dilakukan pada hari yang sama saat pertemuan kedua berakhir. Soebagio (2000) menyatakan bahwa model pembelajaran kooperatif tipe TGT merupakan strategi pembelajaran yang dapat dilakukan secara luwes dan mengandung unsur permainan sehingga akan membuat siswa belajar dengan suasana yang menyenangkan sehingga materi yang diberikan akan mudah diserap dan diingat siswa.

Kegiatan belajar di kelas eksperimen dengan menggunakan model pembelajaran kooperatif tipe TGT dengan berbantuan media teka-teki silang membuat siswa lebih antusias dalam kegiatan belajar mengajar. Hal tersebut sesuai dengan hasil wawancara ke siswa yang mengungkapkan jika materi Kimia yang bersifat hapalan diajarkan dengan metode yang mengandung unsur permainan akan membuat siswa lebih tertantang untuk mengikuti pelajaran. Hasil penelitian juga menunjukkan bahwa siswa di kelas eksperimen dalam mengikuti pembelajaran terlihat sangat antusias dan bersemangat pada saat guru menyajikan 
materi dengan menggunakan model kooperatif tipe TGT. Rakhmadani, dkk. (2013) yang menyatakan bahwa pada saat penerapan model pembelajaran akan meningkatkan motivasi belajar siswa di kelas eksperimen.

Motivasi belajar dapat diketahui setelah melakukan observasi terhadap 40 siswa di kelas kontrol dan kelas eksperimen. Motivasi belajar siswa dalam penelitian dibagi ke dalam 6 aspek berdasarkan Tuan, dkk. (2005). Adapun keenam aspek tersebut adalah efikasi diri, strategi pembelajaran aktif, learning value, tujuan kinerja, tujuan pencapaian, dan stimulasi lingkungan belajar. Motivasi belajar siswa diamati oleh 2 observer. Rata-rata hasil observasi motivasi siswa ditampilkan pada Gambar 1 dan hasil observasi motivasi belajar siswa pada setiap aspek ditampilkan pada Gambar 2.

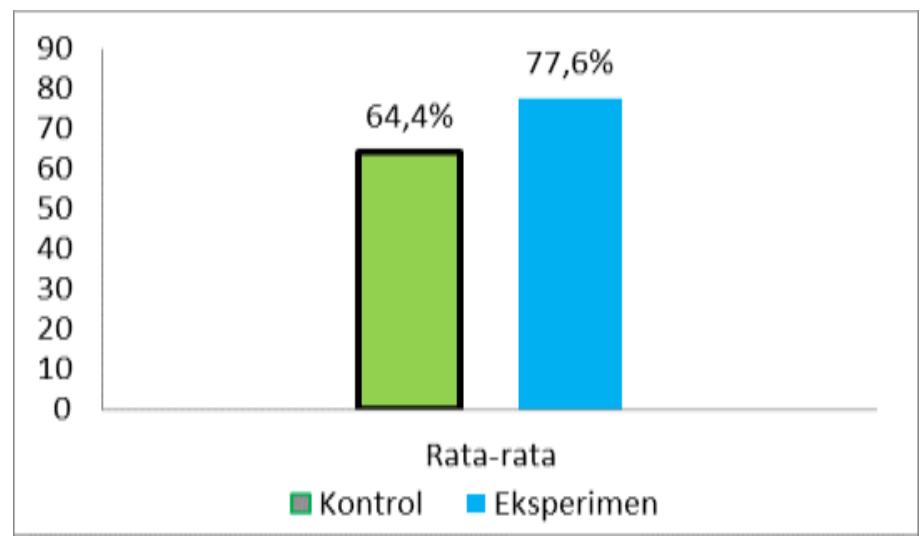

Gambar 1 Rata-Rata Motivasi Belajar Kelas Kontrol dan Eksperimen

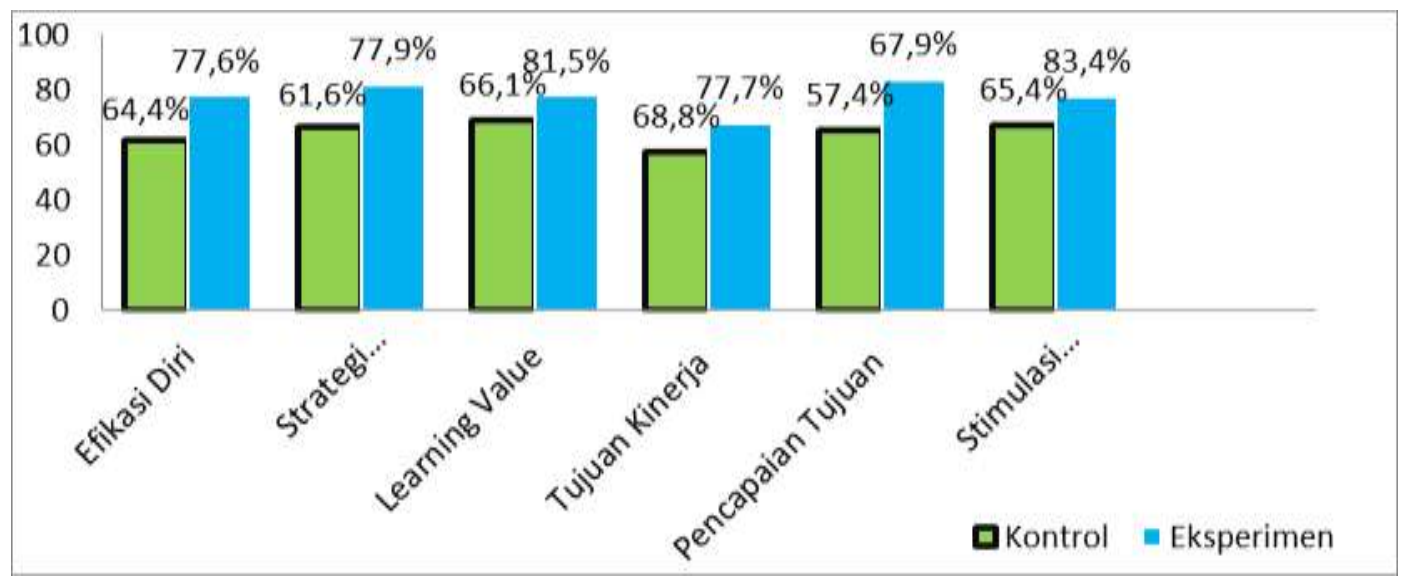

Gambar 2 Motivasi Belajar Siswa Kelas Kontrol dan Eksperimen 
Motivasi belajar siswa kelas kontrol memiliki rentang nilai minimum sebesar 48,02 dan nilai maksimum sebesar 76,02 dengan rata-rata nilai motivasi belajar siswa kelas kontrol sebesar 64,4\% (Gambar 1). Motivasi belajar kelas eksperimen memiliki rentang nilai minimum sebesar 60,56 dan nilai maksimum sebesar 93,78 dengan rata-rata nilai motivasi belajar siswa kelas eksperimen sebesar 77,6\% (Gambar 1). Gambar 2 menunjukkan bahwa di kelas kontrol persentase yang paling rendah terletak pada aspek tujuan kinerja, sedangkan aspek learning value memiliki persentase paling tinggi. Pada kelas eksperimen persentase yang paling rendah yaitu aspek tujuan kinerja dan aspek dengan persentase paling tinggi terletak pada aspek tujuan pencapaian.

\section{Efikasi Diri (Self Efficacy)}

Hasil persentase motivasi siswa pada aspek efikasi diri di kelas kontrol dan eksperimen ditampilkan pada Gambar 3.

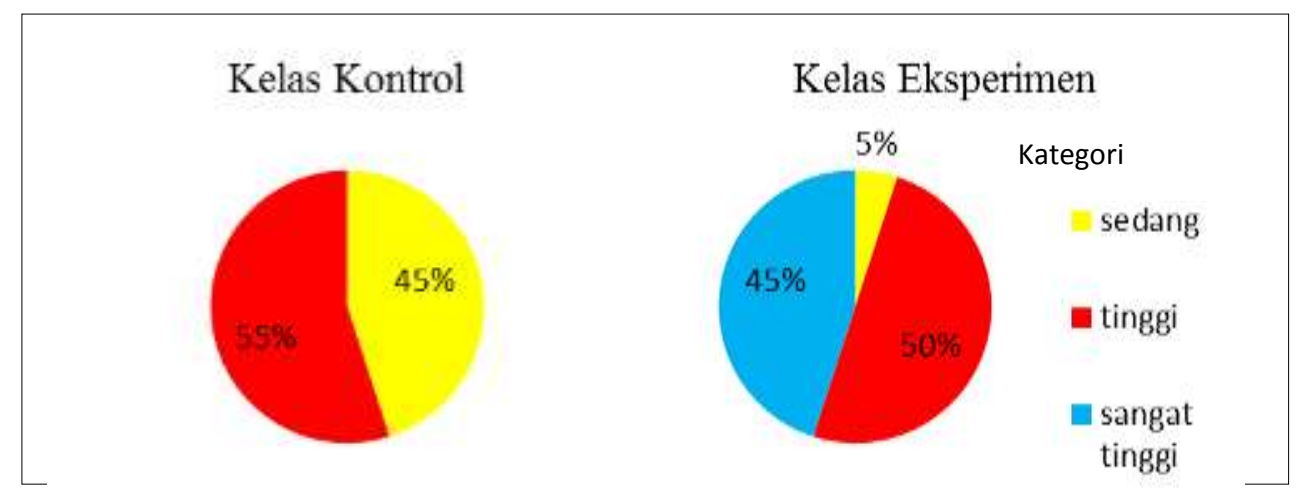

\section{Gambar 3 Persentase Aspek Efikasi Diri Siswa Kelas Kontrol dan Eksperimen}

Efikasi diri (Self efficacy) yang dimaksud dalam penelitian adalah siswa percaya terhadap kemampuannya sendiri untuk melakukan atau menyelesaikan tugas-tugas belajar dengan baik (Tuan, dkk., 2005). Rata-rata nilai efikasi diri siswa kelas kontrol sebesar 61,6 sedangkan kelas eksperimen yaitu 77,9 yang berarti rata-rata nilai efikasi diri kelas kontrol lebih rendah daripada kelas eksperimen. Hal tersebut juga ditunjukkan dengan persentase siswa kategori tinggi dan sangat tinggi. Persentase siswa dengan kategori tinggi di kelas kontrol hanya sebesar 55\% sedangkan di kelas eksperimen persentase siswa pada kategori 
sangat tinggi berjumlah 90\% (Gambar 3). Tahapan pembelajaran kooperatif tipe TGT dapat meningkatkan efikasi diri siswa yaitu terlihat pada saat proses pembelajaran siswa banyak mengacungkan tangan pada saat guru memberikan pertanyaan kepada siswa. Siswa sangat percaya terhahap kemampuannya untuk melakukan dan menyelesaikan tugas yang diberikan oleh guru dengan baik.

\section{Strategi Pembelajaran Aktif (Active Learning Strategy)}

Strategi pembelajaran aktif yang dimaksud dalam penelitian adalah siswa yang berperan aktif dalam penggunaan berbagai strategi untuk membangun pengetahuan baru berdasarkan pemahaman siswa sebelumnya (Tuan, dkk., 2005). Persentase nilai motivasi siswa pada aspek strategi pembelajaran aktif disajikan pada Gambar 4.

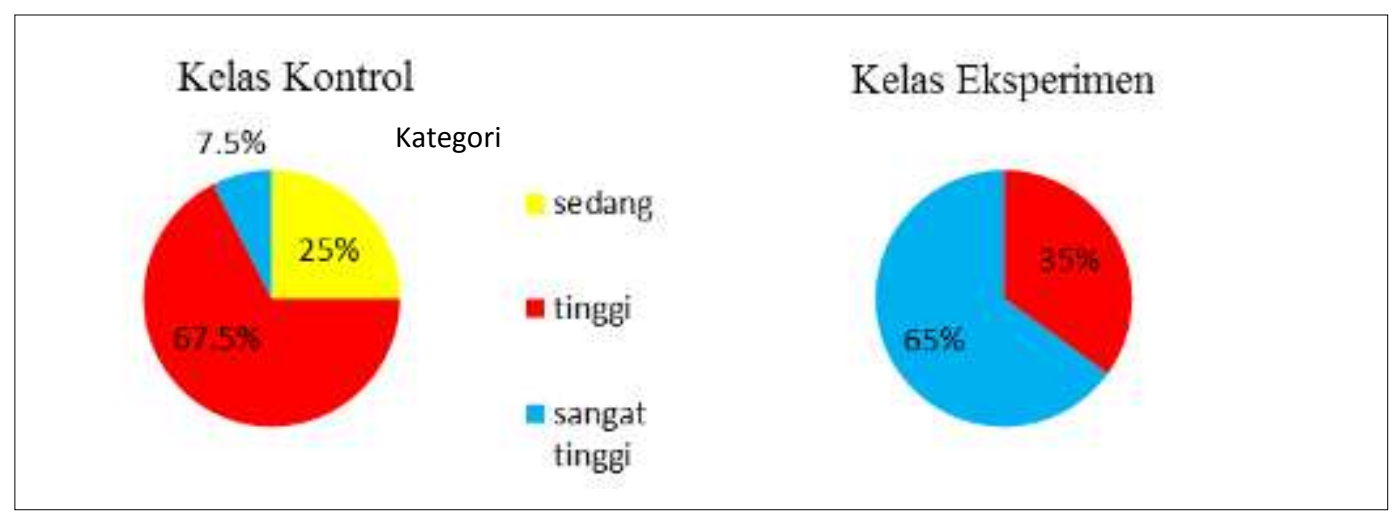

\section{Gambar 4. Persentase Aspek Strategi Pembelajaran Aktif Siswa Kelas Kontrol dan Kelas Eksperimen}

Nilai rata-rata strategi pembelajaran aktif siswa kelas kontrol yaitu 66,1 sedangkan pada kelas eksperimen 81,5. Gambar 4 menunjukkan bahwa aspek strategi pembelajaran aktif siswa kelas kontrol lebih rendah dibandingkan dengan kelas eksperimen. Hal tersebut ditunjukkan dari hasil persentase siswa dengan kategori tinggi dan sangat tinggi. Aspek strategi pembelajaran aktif merupakan faktor yang memiliki korelasi tertinggi kedua setelah aspek efikasi diri untuk meningkatkan hasil belajar siswa karena siswa dilibatkan langsung dalam penggunakan strategi saat proses pembelajaran berlangsung (Tuan, dkk., 2005). Saat proses pembelajaran berlangsung di kelas eksperimen dengan menggunakan model kooperatif tipe TGT berbantuan media TTS, siswa sangat berperan aktif 
dalam penggunaan strategi yang diterapkan oleh guru sehingga dapat membangun pengetahuan baru berdasarkan pemahaman siswa sebelumnya.

\section{Nilai Pembelajaran Sains (Science Learning Value)}

Learning value yang dimaksud dalam penelitian adalah merangsang pemikiran siswa dengan menemukan hal-hal yang berkaitan dengan materi dalam kehidupan sehari-hari (Tuan, dkk., 2005). Rata-rata dari nilai pembelajaran Kimia pada kelas kontrol yaitu 68,8 sedangkan pada kelas eksperimen 77,7. Persentase siswa kelas kontrol dan kelas eksperimen pada aspek nilai pembelajaran Kimia dapat dilihat pada Gambar 5.

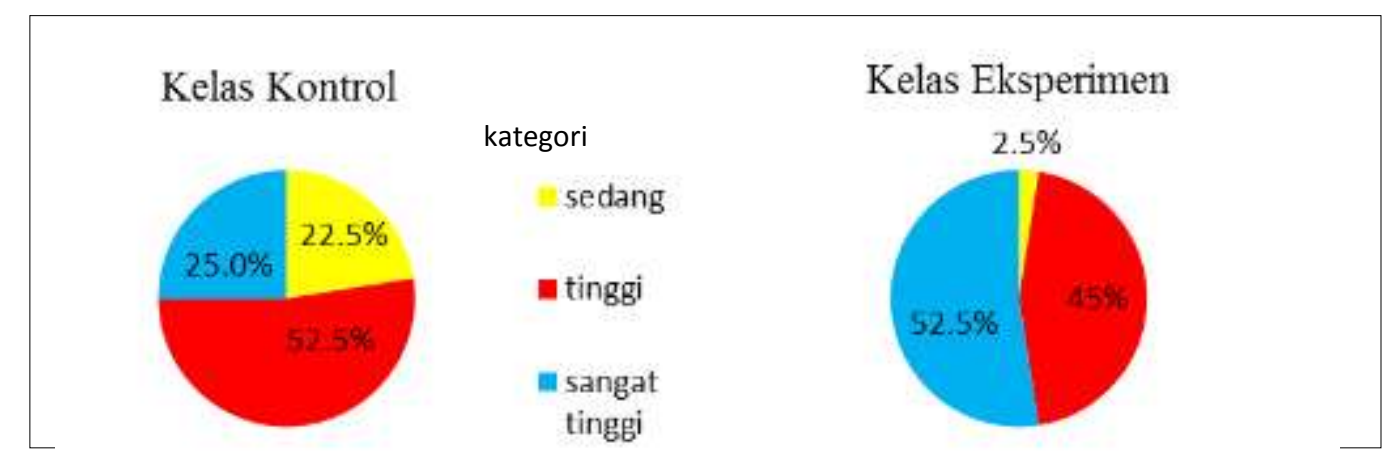

Gambar $\supset$ Persentase Aspek Nilai Pembelajaran Kimia Siswa Kelas Kontrol dan Eksperimen

Berdasarkan Gambar 5, dapat disimpulkan bahwa science learning value di kelas eksperimen memperoleh persentase yang lebih tinggi dibandingkan kelas kontrol. Persentase siswa di kelas kontrol pada kategori tinggi dan sangat tinggi berturut-turut hanya $52,5 \%$ dan $25 \%$ sedangkan di kelas eksperimen pada kategori tinggi dan sangat tinggi masing-masing sebesar $45 \%$ dan 52,5\%. Saat proses pembelajaran berlangsung siswa terlihat sangat antusias dalam menemukan halhal yang berkaitan dengan materi dalam kehidupan sehari-hari, sehingga dengan demikian pemikiran siswa dapat terangsang dalam menemukan hal-hal yang baru.

\section{Tujuan Kinerja (Performance Goal)}

Tujuan kinerja yang dimaksud dalam penelitian adalah tujuan siswa dalam mempelajari ilmu kimia adalah untuk bersaing dengan siswa lain dalam 
mendapatkan nilai yang memuaskan (Tuan, dkk., 2005). Hasil persentase motivasi siswa pada aspek tujuan kinerja disajikan pada Gambar 6.

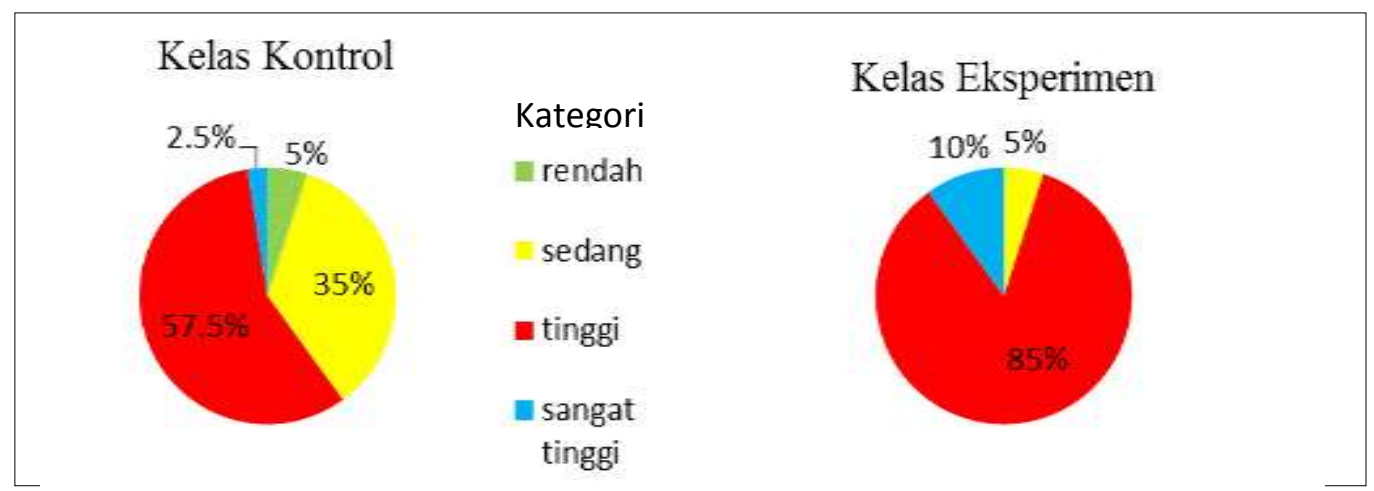

\section{Gambar 6 Persentase Aspek Tujuan Kinerja Siswa Kelas Kontrol dan Eksperimen}

Nilai rata-rata tujuan kinerja siswa kelas eksperimen yaitu 67,9 lebih tinggi dibandingkan kelas kontrol yaitu 57,4. Berdasarkan Gambar 6, persentase aspek tujuan kinerja di kelas kontrol memperoleh persentase yang lebih rendah dibandingkan dengan kelas eksperimen. Siswa dengan kategori tinggi dan sangat tinggi di kelas eksperimen memperoleh persentase yang lebih besar yaitu secara berturut-turut $85 \%$ dan $10 \%$. Sedangkan pada kelas kontrol dengan kategori tinggi dan sangat tinggi hanya $57,5 \%$ dan $2,5 \%$. Pada saat proses pembelajaran siswa sangat aktif dalam mengikuti setiap proses pembelajaran yang disajikan oleh guru dan terlihat adanya persaingan yang sehat antara kelompok siswa satu dengan yang lain. Persaingan antara kelompok satu dengan yang lain karena siswa berlomba untuk mendapatkan nilai yang memuaskan dan mendapatkan penghargaan di akhir proses pembelajaran.

\section{Tujuan pencapaian (Achievement Goal)}

Tujuan pencapaian yang dimaksud dalam penelitian adalah siswa merasa puas karena siswa dapat meningkatkan kompetensi dan prestasi siswa selama proses kegiatan belajar berlangsung (Tuan, dkk., 2005). Nilai rata-rata tujuan pencapaian siswa kelas kontrol yaitu 67,0 sedangkan pada kelas eksperimen 77,3. Persentase nilai pada aspek tujuan pencapaian dapat dilihat dari Gambar 7. 


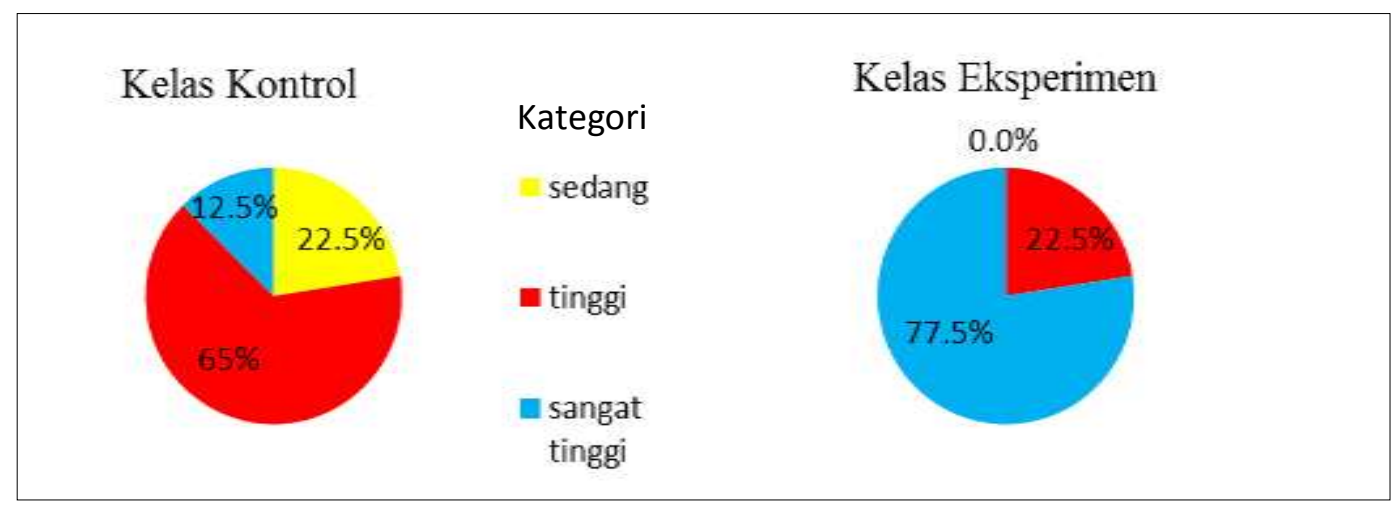

Gambar 7 Persentase Aspek Tujuan pencapaian Siswa Kelas Kontrol dan Eksperimen

Gambar 7 menunjukkan bahwa siswa di kelas eksperimen memiliki persentase pada aspek tujuan pencapaian yang lebih tinggi dibandingkan dengan siswa kelas kontrol. Persentase siswa dengan kategori tinggi di kelas eksperimen $22,5 \%$ dan kategori sangat tinggi 77,5\% sedangkan di kelas kontrol pada kategori tinggi $65 \%$ dan kategori sangat tinggi hanya 12,5\%. Aspek tujuan pencapaian menurut penelitian yang dilakukan oleh Tuan, dkk. (2005) merupakan aspek yang memiliki korelasi terhadap sikap ilmiah. Dalam proses pembelajaran siswa terlihat sangat puas dengan hasil yang mereka dapatkan sehingga pada akhir pembelajaran tim yang terbaik akan mendapatkan reward.

\section{Stimulasi Lingkungan Belajar (Learning Environment Stimulation)}

Stimulasi lingkungan belajar yang dimaksud dalam penelitian yaitu pengajaran guru, lingkungan sekitar, dan interaksi siswa juga mempengaruhi motivasi siswa dalam belajar (Tuan, dkk., 2005). 


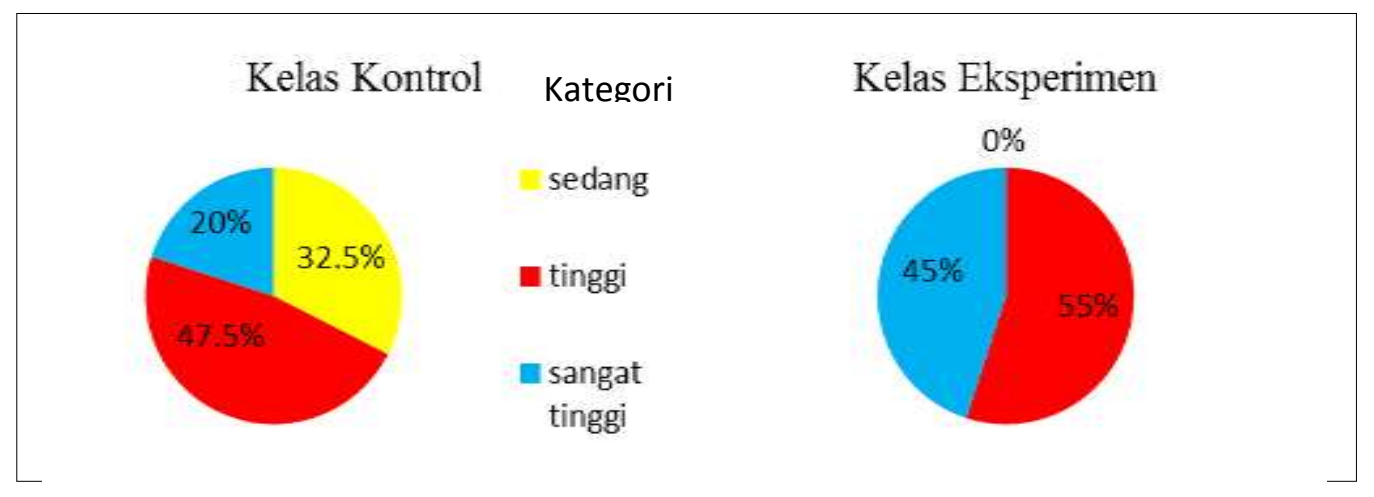

\section{Gambar 8 Persentase Aspek Stimulasi Lingkungan Belajar Kelas Kontrol dan Eksperimen}

Nilai rata-rata tujuan pencapaian siswa pada kelas kontrol yaitu 67,0 sedangkan pada kelas eksperimen yaitu 77,3. Dari data persentase yang diperoleh dari Gambar 8, dapat disimpulkan bahwa motivasi siswa pada aspek stimulasi lingkungan belajar kelas eksperimen lebih tinggi dibandingkan dengan kelas kontrol karena pada saat proses pembelajaran berlangsung, interaksi antara siswa terjalin dengan baik dan siswa aktif bertanya kepada guru. Aspek stimulasi lingkungan belajar menurut penelitian yang dilakukan oleh Tuan, dkk. (2005), merupakan aspek yang memiliki korelasi yang sangat tinggi terhadap sikap ilmiah siswa. Selama proses pembelajaran berlangsung, interaksi antara siswa satu dengan yang lain terlihat sangat baik sehingga tercipta suasana kelas yang aktif dan kompetitif.

Perbedaan Motivasi Belajar Siswa Kelas Kontrol dan Eksperimen Tabel 1 Hasil Uji Statistik Motivasi Belajar

\begin{tabular}{lcl}
\hline Uji & Signifikansi & \multicolumn{1}{c}{ Kesimpulan } \\
\hline Uji Kolmogorov-Smirnov & & \\
Kelas Kontrol & 0,20 & Data terdistribusi normal \\
Kelas Eksperimen & 0,20 & Data terdistribusi normal \\
Uji F & 0,00 & Varian kedua data tidak homogeny \\
Uji t dengan asumsi & 0,00 & Terdapat perbedaan motivasi belajar \\
varian tidak homogen & & \\
\hline
\end{tabular}

Motivasi belajar siswa dianalisis dengan menggunakan uji statistik (Tabel 1). Motivasi belajar kelas eksperimen dan kelas kontrol terdistribusi normal 
dengan nilai 0,20 untuk kelas eksperimen dan kontrol yang lebih dari 0,05. Selanjutnya diuji dengan uji $\mathrm{F}$ untuk menentukan homogenitas varian sampel dan didapat nilai signifikansi 0,00 yaitu kurang dari 0,05 yang berarti kedua data tersebut tidak homogen. Selanjutnya, data diuji dengan menggunakan uji t dengan asumsi varian tidak homogen dan didapat nilai signifikansi 0,00 yaitu kurang dari 0,05 yang berarti terdapat perbedaan motivasi belajar siswa. Perbedaan motivasi siswa dikarenakan adanya perbedaan penerapan model pembelajaran. Kelas eksperimen menggunakan model pembelajaran kooperatif tipe TGT berbantuan media TTS membuat siswa lebih aktif dalam mengikuti pembelajaran sehingga siswa termotivasi untuk belajar. Berbeda dengan kelas kontrol yang menggunakan metode ceramah. Besar nilai effect size motivasi siswa sebesar 1,83 dengan persentase $96,64 \%$.

\section{SIMPULAN}

Berdasarkan hasil analisis, maka dapat disimpulkan terdapat perbedaan motivasi belajar siswa yang diajarkan dengan menggunakan metode ceramah dan model pembelajaran kooperatif tipe Teams Games Tournament (TGT) berbantuan media Teka-Teki Silang (TTS) pada materi Koloid. Pengaruh model pembelajaran kooperatif tipe TGT terhadap motivasi sebesar 96,64\% dan nilai effect size motivasi siswa sebesar 1,83 .

\section{DAFTAR PUSTAKA}

Hamalik, O. 2011. Kurikulum dan Pembelajaran. Jakarta: Bumi Aksara.

Hamdu, G. \& Agustina, L. 2011. Pengaruh Motivasi Belajar Siswa terhadap Prestasi Belajar IPA di Sekolah Dasar. Jurnal Penelitian Pendidikan, 12(1): 81-86.

Khalilullah, M. 2013. Permainan Teka-Teki Silang sebagai Media dalam Pembelajaran Bahasa Arab (Mufradat). Jurnal Pemikiran Islam, 37(1): 1526.

Mulyatiningsih, E. 2012. Metode Penelitian Terapan Bidang Pendidikan. Bandung: Alfabeta.

Rakhmadani, N., Yamtinah, S., \& Utomo, S. B. 2013. Pengaruh Penggunaan Metode Teams Game Tournament Berbantuan Media Teka-Teki Silang dan Ular Tangga dengan Motivasi Belajar terhadap Prestasi Siswa pada Materi 
Koloid Kelas XI SMA Negeri 1 Simo Tahun Pelajaran 2011/2012. Jurnal Pendidikan Kimia (JPK), 2(4): 190-197.

Soebagio. 2000. Penggunaan Pembelajaran Kooperatif Model TGT untuk Peningkatan Kualitas Pembelajaran Konsep Larutan Asam Basa. Jakarta: PPGSM.

Sugiyono. 2011. Metode Penelitian Kualitatif, Kuantitatif dan $R \&$ D. Jakarta: Alfabeta.

Tuan, H. L., Chin, C. C., \& Shieh, S. H. 2005. The Development of a Questionnaire to Measure Student's Motivation Towards Science Learning. International Journal of Science Education, 27(6): 639-654. 